\title{
Holocene vegetation, fire and land use dynamics at Lake Svityaz, an agriculturally marginal site in northwestern Ukraine
}

\author{
Christoph Schwörer ${ }^{1,2}$ (D) Erika Gobet ${ }^{1,2} \cdot$ Jacqueline F. N. van Leeuwen ${ }^{1} \cdot$ Sarah Bögli ${ }^{1} \cdot$ Rachel Imboden $^{1}$. \\ W. O. van der Knaap ${ }^{1} \cdot$ Nadezhda Kotova $^{3} \cdot$ Sergej Makhortykh $^{3} \cdot$ Willy Tinner $^{1,2}$
}

Received: 26 February 2021 / Accepted: 22 May 2021 / Published online: 21 June 2021

(c) The Author(s) 2021

\begin{abstract}
Observing natural vegetation dynamics over the entire Holocene is difficult in Central Europe, due to pervasive and increasing human disturbance since the Neolithic. One strategy to minimize this limitation is to select a study site in an area that is marginal for agricultural activity. Here, we present a new sediment record from Lake Svityaz in northwestern Ukraine. We have reconstructed regional and local vegetation and fire dynamics since the Late Glacial using pollen, spores, macrofossils and charcoal. Boreal forest composed of Pinus sylvestris and Betula with continental Larix decidua and Pinus cembra established in the region around 13,450 cal вP, replacing an open, steppic landscape. The first temperate tree to expand was Ulmus at 11,800 cal ве, followed by Quercus, Fraxinus excelsior, Tilia and Corylus ca. 1,000 years later. Fire activity was highest during the Early Holocene, when summer solar insolation reached its maximum. Carpinus betulus and Fagus sylvatica established at ca. 6,000 cal BP, coinciding with the first indicators of agricultural activity in the region and a transient climatic shift to cooler and moister conditions. Human impact on the vegetation remained initially very low, only increasing during the Bronze Age, at ca. 3,400 cal BP. Large-scale forest openings and the establishment of the present-day cultural landscape occurred only during the past 500 years. The persistence of highly diverse mixed forest under absent or low anthropogenic disturbance until the Early Middle Ages corroborates the role of human impact in the impoverishment of temperate forests elsewhere in Central Europe. The preservation or reestablishment of such diverse forests may mitigate future climate change impacts, specifically by lowering fire risk under warmer and drier conditions.
\end{abstract}

Keywords Biodiversity $\cdot$ Climate change $\cdot$ Human impact $\cdot$ Macrofossils $\cdot$ Palaeoecology $\cdot$ Pollen analysis

\section{Introduction}

The Neolithic revolution, which established a sedentary lifestyle with agricultural products as the main food source in early human societies, had a significant impact on natural ecosystems in Central Europe. Not only did people in the

Communicated by F. Bittmann.

Christoph Schwörer

christoph.schwoerer@ips.unibe.ch

1 Institute of Plant Sciences, University of Bern, Altenbergrain 21, 3013 Bern, Switzerland

2 Oeschger Centre for Climate Change Research, University of Bern, Hochschulstraße 4, 3012 Bern, Switzerland

3 Institute of Archaeology, National Academy of Sciences of Ukraine, 12 Geroiv Stalingrada prospekt, Kyiv 04210, Ukraine
Neolithic introduce new species such as crops or adventives (Behre 1981; Lang 1994), they also directly affected the species composition and structure of the existing natural forest by using fire to clear areas for arable farming, selective logging of tree species and browsing by domesticated animals (Lang 1994; Ralska-Jasiewiczowa et al. 2003; Tinner and Lotter 2006; Schwörer et al. 2015; Roberts et al. 2018; Rey et al. 2019). Such anthropogenic disturbance led to the widespread decline of disturbance-sensitive taxa such as Tilia, Ulmus or Abies alba in Central European forests and promoted disturbance-adapted trees, shrubs and herbaceous apophytes (Behre 1981; Birks and Tinner 2016; Rey et al. 2019). In the case of Ulmus, the rapid decline all over northwestern Europe in the mid-Holocene has also been attributed to the spread of a pathogen (Peglar 1993; Parker et al. 2002), although the remarkable coincidence with the Neolithic transition over large spatial scales indicates that humans might have played a role after all, possibly by indirectly facilitating 
the spread of the pathogen (Parker et al. 2002; Ralska-Jasiewiczowa et al. 2003). The increasing pressure of anthropogenic disturbance over millennia led to a decrease in tree species diversity, in some cases resulting in almost monospecific forests of disturbance-tolerant or actively favoured tree species such as Picea abies (Norway spruce) or Larix decidua (European larch) in the Alps (Gobet et al. 2003; Schwörer et al. 2015) or Fagus sylvatica (European beech), Quercus robur (pedunculate oak) or Pinus sylvestris (Scots pine) in Central Europe (Ralska-Jasiewiczowa et al. 2003; Bobek et al. 2018; Rey et al. 2019).

From its origin in the Levant, the Neolithisation spread to Anatolia, then arrived around 8,800-8,500 calibrated years before present (cal вр) on the European mainland in Greece (Reingruber and Thissen 2009; Kotsakis 2014), and then advanced via the Balkans around 7,500 cal BP to Central Europe (Ammerman and Cavalli-Sforza 1971; Pinhasi et al. 2005; Tinner et al. 2007; Skoglund et al. 2012; Hofmanová et al. 2016; Gassner et al. 2020). However, other pathways have been proposed that better explain local archaeological findings, such as via islands in the Mediterranean Sea towards Northern Italy, Southern France and the Iberian Peninsula (Guilaine 2018), via the western Black Sea and the Dniestr river to northeastern Europe (Betti et al. 2020), or even via the Caucasus or eastern Black Sea coast to the Ukrainian steppes and onwards to Central Europe (Kotova 2009). Moreover, local domestication or cultivation efforts may have started already during the Mesolithic, before the full Neolithisation material package was introduced (e.g. Tinner et al. 2007; Miras et al. 2010; Lambert et al. 2019).

Since the spread of the Neolithic in Europe also coincided with major climatic changes after 8,200 cal вр (Tinner and Lotter 2006) and was in turn also influenced by climatic factors (Betti et al. 2020), it is difficult to determine if temperate forest dynamics are driven mostly by climate or anthropogenic impact, or a combination of both. Approaches that overcome these limitations include rigorous multi-proxy studies with independent lines of evidence, high-resolution time-series analyses (Tinner et al. 1999; Schwörer et al. 2015; Rey et al. 2019) or the combination of palaeoecological analyses with dynamic vegetation modelling (Heiri et al. 2006; Henne et al. 2013; Schwörer et al. 2014). Another approach is to study natural forest dynamics under low or absent human impact, for example in peripheral areas that were either too remote for agriculture or less well suited, e.g. due to poor or waterlogged soils. This applies to the western Polesie region in Central Europe, one of the largest forested regions of the continent with a low population density due to extensive marshes and nutrient-poor, sandy soils that prevent large-scale agriculture. By contrasting vegetation dynamics from marginal areas with sites with excellent conditions (e.g. fertile loess or morainic soils) that have been heavily impacted by human activity for millennia, we can assess the role of human disturbance and identify the nearnatural vegetation under climatic conditions comparable to those of today and the recent past. Here, we present a novel vegetation reconstruction based on pollen, macrofossil and charcoal analyses from Lake Svityaz, at the border triangle of present-day Ukraine, Belarus and Poland. We are particularly interested in addressing the following research questions: (1) How did the vegetation react to climatic changes since the Late Glacial period; (2) What is the timing and impact of the first agricultural activities in our study area; (3) Can we use the Lake Svityaz sediment record to check if the impoverishment of forests in Central Europe is driven by human impact? Our results may help ecosystem managers to assess the potential natural vegetation of this area and maintain ecosystem services in a warmer and drier future.

\section{Methods}

\section{Study site}

Lake Svityaz (Озеро Світязь) is the deepest lake in the Ukraine with a maximum water depth of $58.4 \mathrm{~m}$. With a surface are of $25.2 \mathrm{~km}^{2}$ and a catchment area of $43.6 \mathrm{~km}^{2}$, it is also the second largest lake in the country and part of the Shatsk lake district, which is protected as a national park, a Ramsar site and a UNESCO biosphere reserve. The lake lies in the southwestern part of the Polesie region, within the Western Bug basin in the Volyn province, close to the borders of Poland and Belarus (Fig. 1). It is of karstic origin and is located ca. $300 \mathrm{~km}$ south of the range of the last glaciation. In 1887, the lake was connected to nearby Lake Luka by a $3 \mathrm{~km}$ long channel, which led to a lowering of the water table by $3 \mathrm{~m}$ (Tarasov et al. 1996). The geology of the area is characterized by Upper Cretaceous carbonate rocks, overlain by Quaternary glaciogenic and fluvial deposits such as sands and till (Dobrowolski et al. 2010, 2015). The topography is very flat with only minor elevation changes. The climate in the study area is temperate continental with warm summers, cool winters and rather low precipitation. Average July and January temperatures at the nearby weather station of Włodawa are $17.2^{\circ} \mathrm{C}$ and $-4.1^{\circ} \mathrm{C}$ respectively for the normal period 1981-2010. The mean annual precipitation is $500 \mathrm{~mm}$ with highest values during the summer months (Meteostat 2021). The vegetation in the study area is a mosaic of forests, pine plantations, marshes, peatlands and meadows. The forests are mixed temperate oak forests dominated by Quercus robur and Pinus sylvestris but also contain many other deciduous species such as Betula pendula (silver birch), Fraxinus excelsior (common ash), 


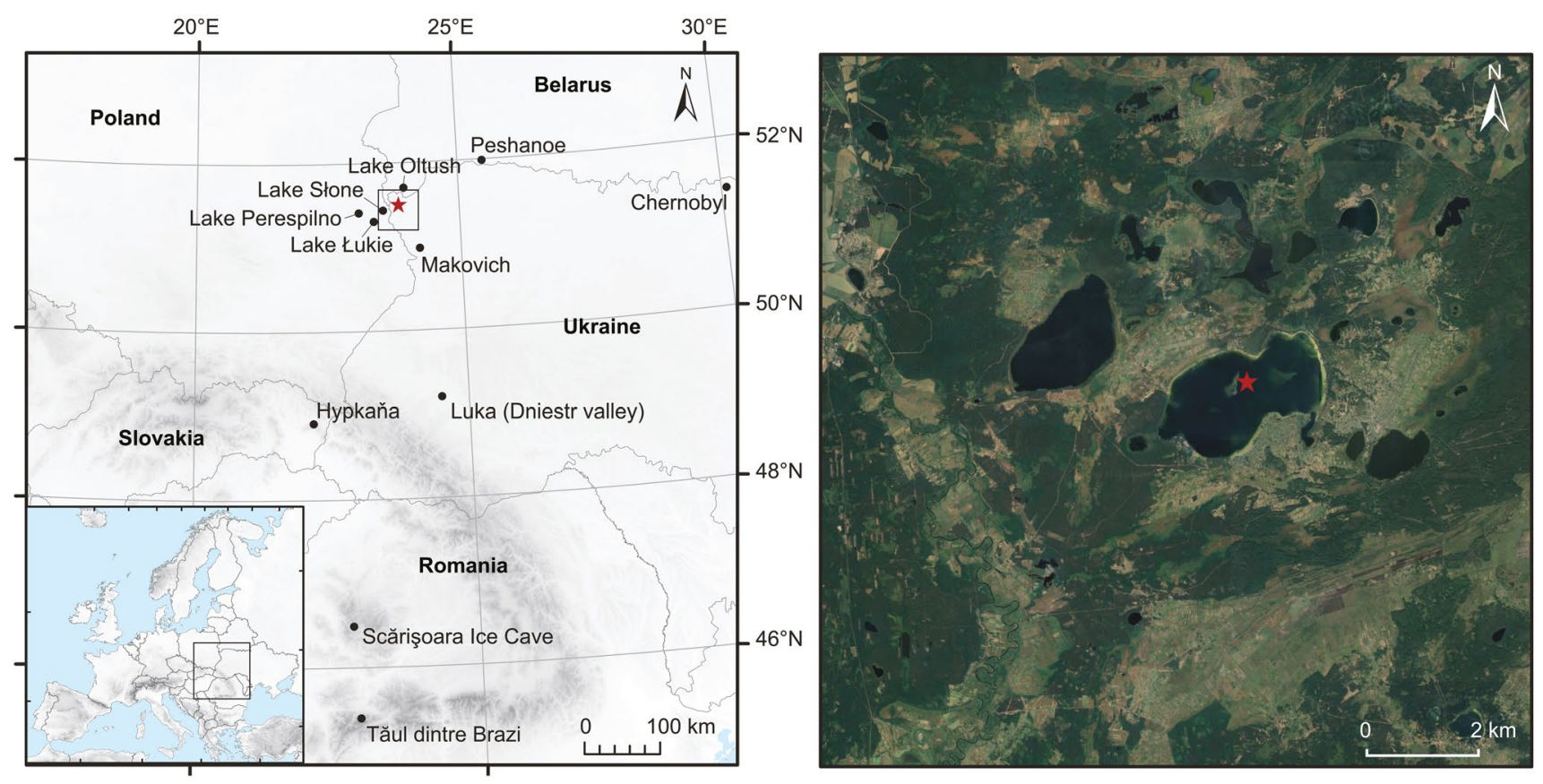

Fig. 1 Location of the study site and other palaeoecological and palaeoclimatic records in Central Eastern Europe (left) and the coring location in Lake Svityaz (red star)

Tilia cordata (small-leaved linden) and Carpinus betulus (common hornbeam).

\section{Lake sediment coring and subsample preparation}

In July 2011, we retrieved two parallel sediment cores with a UWITEC piston corer at a water depth of $12 \mathrm{~m}$ (Fig. 1; $51.505^{\circ} \mathrm{N}, 23.843^{\circ} \mathrm{E} ; 157 \mathrm{~m}$ a.s.l.). We split the cores horizontally in the laboratory and assembled them to a composite master core of $12.3 \mathrm{~m}$ using visual correlation of distinct sediment layers. For pollen and microscopic charcoal analysis, we took 103 subsamples of $1 \mathrm{~cm}^{3}$ at regular intervals and processed these using standard procedures with $\mathrm{HCl}, \mathrm{KOH}$, $\mathrm{HF}$, acetolysis and mounting in glycerine (Moore et al. 1991). To estimate pollen and charcoal concentration and influx we added Lycopodium tablets with a known number of spores prior to the chemical treatment (Stockmarr 1971). We identified pollen, spores and other non-pollen palynomorphs (NPP) under a light microscope at $400 \times$ magnification using published keys (e.g. Moore et al. 1991; Reille 1999; Beug 2004) and the reference collection at the University of Bern. We counted a minimum number of 500 pollen grains excluding aquatic plants and spores (average 843 pollen grains) with the exception of two samples at the bottom of the core, where the pollen sum was 318 and 410. In total we identified 216 different pollen, spore and NPP-types. We also identified and counted plant stomata in the pollen slides using the key of Trautmann (1953) and the illustrations in Finsinger and Tinner (2020). Microscopic charcoal particles $>10 \mu \mathrm{m}$ were counted on the pollen slides following Tinner and $\mathrm{Hu}$ (2003) and Finsinger and Tinner (2005). We subdivided the pollen data into statistically significant local pollen assemblage zones (LPAZ) using optimal partitioning with minimal sum-of-squares (Birks and Gordon 1985) and the brokenstick model (Bennett 1996) using the software R 3.5 (R Core Team 2015). For the macrofossil analysis, we took 75 subsamples with a thickness of $2 \mathrm{~cm}$ and a volume of $8-15 \mathrm{~cm}^{3}$ and sieved them with a mesh size of $200 \mu \mathrm{m}$. We identified plant remains under a stereomicroscope at $10-50 \times$ magnification using published keys (e.g. Schoch et al. 1988), as well as the reference collection at the University of Bern. Macrofossil concentrations were standardized to a volume of $8 \mathrm{~cm}^{3}$.

\section{Chronology}

Radiocarbon dating was carried out at the Poznan University Radiocarbon Laboratory and the Laboratory for the Analysis of Radiocarbon with AMS (LARA) at the University of Bern. The dates were calibrated to years before present (cal BP) using the IntCal13 calibration curve (Reimer et al. 2013). The age-depth model of Lake Svityaz was calculated based on 9 AMS radiocarbon dates from terrestrial plant remains (Table 1), using the program Clam (Blaauw 2010) with Monte Carlo sampling with 10,000 iterations and a monotonic spline function. Additionally, we calculated an extended $95 \%$ confidence envelope using mixed-effect 
Table 1 Radiocarbon dates and calibrated ages used to calculate the age-depth model of the Lake Svityaz sediment record

\begin{tabular}{|c|c|c|c|c|c|}
\hline Depth $(\mathrm{cm})$ & Lab. code & Material dated & ${ }^{14} \mathrm{C}$-Age (year вр) & Cal. age, $2 \sigma$ (cal вр) & $\begin{array}{l}\text { Age in } \\
\text { diagram } \\
\text { (cal } \mathrm{BP})\end{array}$ \\
\hline $148-150$ & Poz-51308 & Terrestrial leaf fragments, Betula S, coniferous BS & $890 \pm 60$ & $922-703$ & 815 \\
\hline $281-285$ & Poz-51309 & $\begin{array}{l}\text { Terrestrial leaf fragments, Betula S, coniferous BS, decidu- } \\
\text { ous P }\end{array}$ & $2,610 \pm 35$ & $2,788-2,622$ & 2,742 \\
\hline $430-436$ & BE-6930.1.1 & Terrestrial leaf fragments, Betula S \& FS & $4,345 \pm 100$ & $5,295-4,650$ & 4,978 \\
\hline $564-568$ & Poz-51310 & Terrestrial leaf fragments, Betula $\mathrm{S}$, coniferous $\mathrm{P}$ & $5,520 \pm 70$ & $6,446-6,190$ & 6,322 \\
\hline $656-660$ & BE-6728.1.1 & Terrestrial leaf fragments, Betula $\mathrm{S}$, deciduous $\mathrm{P}$ & $6,245 \pm 65$ & $7,301-6,983$ & 7,149 \\
\hline $750-754$ & BE-6727.1.1 & Terrestrial leaf fragments, Betula S \& FS & $7,530 \pm 65$ & $8,424-8,194$ & 8,328 \\
\hline $867-869$ & Poz-51311 & Betula $\mathrm{S} \& \mathrm{FS}$, indet. $\mathrm{S}$, coniferous $\mathrm{BS}$, deciduous $\mathrm{P}$ & $11,640 \pm 50$ & $13,575-13,371^{*}$ & - \\
\hline 954-956 & BE-6726.1.1 & Twig indet., deciduous BS, Betula S, bud indet & $10,455 \pm 60$ & $12,556-12,112$ & 12,350 \\
\hline $1,016-1,018$ & Poz-51307 & Terrestrial leaf fragments, coniferous BS, deciduous $\mathrm{P}$ & $11,290 \pm 50$ & $13,254-13,065$ & 13,150 \\
\hline
\end{tabular}

$S$ seed, $B S$ budscale, $P$ periderm, $F S$ fruitscale

*Rejected

modelling, taking into account the within object variance (calibration error) as well as the between object variance (sample thickness), according to Heegard et al. (2005).

\section{Numerical analyses}

To identify gradients in the vegetation composition over time, we used ordination analysis (ter Braak and Prentice 1988; Legendre and Birks 2012). We first analyzed the untransformed pollen data with a detrended correspondence analysis (DCA) using the software CANOCO 5.1 (ter Braak and Šmilauer 2017) to choose the appropriate response model (unimodal or linear). Since the gradient was rather short (1.9 SD) we decided to use a linear method, i.e. principal component analysis (PCA) with square-root transformation of the pollen percentage data.

To estimate biodiversity changes during the Holocene, we used palynological richness (PRI), the probability of interspecific encounter (PIE) and evenness-detrended palynological richness (DE-PRI). Palynological richness is the number of different pollen types per sample, calculated using rarefaction analysis with a constant pollen sum of 457 pollen grains per sample (Birks and Line 1992). PRI has been used by several studies to estimate past plant diversity in the landscape (Odgaard 1999; Colombaroli et al. 2013; Schwörer et al. 2015), but can be affected by differences in pollen productivity that modify the palynological evenness of a sample, compared to the evenness of the vegetation (van der Knaap 2009). To assess such potential biases, we calculated PIE according to
Hurlbert (1971) and DE-PRI according to Colombaroli and Tinner (2013). We used the software R 3.5. (R Core Team 2015) with the package vegan (Oksanen et al. 2015) for all numerical analyses unless specified otherwise.

\section{Results and interpretation}

\section{Lithology and chronology}

In total, we retrieved $12.32 \mathrm{~m}$ of lake sediment. The lowermost sediment consists of lake marl $(1,232-1,218 \mathrm{~cm})$ and sand $(1,218-1,054 \mathrm{~cm})$ and did not contain any identifiable pollen or plant remains. Above $1,054 \mathrm{~cm}$ the sediment changes to silt and dark to light brown calcareous gyttja $(1,050-0 \mathrm{~cm})$. The 9 radiocarbon dates from our record span the Late Glacial to Holocene, with the oldest date at 13,255-13,065 cal вр (Table 1; Fig. 2). We had to reject one radiocarbon date at $868 \mathrm{~cm}$ since it is clearly too old and did not fit into the age-depth model. The sediment accumulation rate is fairly linear, with only small changes throughout the record, such as a slight increase from ca. 8,000-5,000 cal вP and during the last 500 years (Fig. 2).

\section{Pollen, macrofossil and charcoal analysis}

We identified 8 statistically significant local pollen assemblage zones (LPAZ; SVI-1-8) that we use to discuss the pollen and macrofossil analysis. 


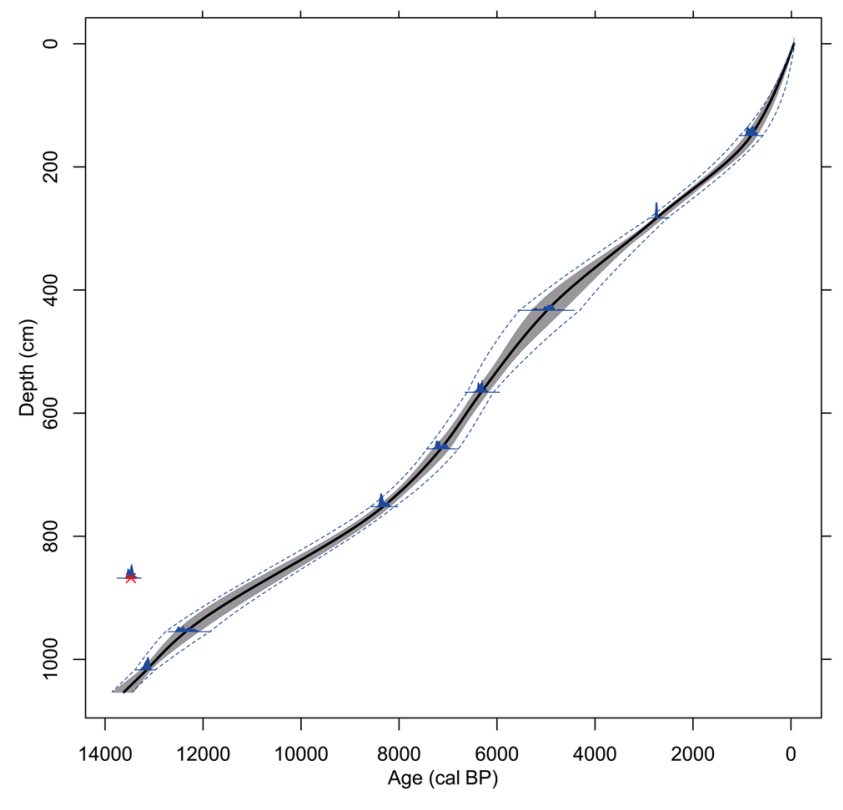

Fig. 2 Age-depth model of the Lake Svityaz sediment record, based on eight calibrated radiocarbon dates (blue density curves). One radiocarbon date was rejected due to an unrealistic age (red cross). The grey area shows the $95 \%$ confidence interval of the age-depth model using Monte Carlo sampling with 10,000 iterations and a monotonic spline function. The dashed blue lines show $95 \%$ confidence intervals of a mixed-effect model, taking into account betweenobject variance (sample thickness; Heegard et al. 2005). The black line shows the best fit of the age-depth model that has been used for drawing the pollen diagram. The age-depth model was calculated using the program clam 2.2 (Blaauw 2010) with the IntCal13 calibration curve (Reimer et al. 2013)

SVI-1 (13,600-13,450 cal BP): The oldest LPAZ has the lowest arboreal pollen (AP) percentages of the entire record, ca. $60 \%$ (Fig. 3). Wind-pollinated Betula is the dominant pollen reaching up to $50 \%$. Rather high values are also reached by Juniperus-type (5\%) and Salix (10\%). Non arboreal pollen (NAP) percentages reach ca. $30 \%$ and are dominated by Poaceae and Artemisia, with considerable shares of Chenopodiaceae and Urtica dioica. Cyperaceae and remains of the green algae Pediastrum spp. reach the highest values of the record. No arboreal macrofossils were found in this LPAZ and only very few, unidentified plant remains (Figs. 3 and ESM). Microscopic charcoal concentration and influx are very low, whereas macroscopic charcoal has been found, although in low quantities. The low AP percentages as well as the absence of arboreal macrofossils suggest a very open landscape surrounding the lake, dominated by steppic elements such as Artemisia and Chenopodiaceae and likely scattered Betula, Salix, Juniperus and possibly Pinus sylvestris trees or shrubs. Burning was rather rare in the steppic environments, likely due to low standing biomass. The maximum of Urtica dioica may have been caused by nitrogen-rich environments, while high abundances of Cyperaceae and Pediastrum may have resulted from low water tables.

SVI-2 (13,450-11,800 cal вр): AP rises to almost $90 \%$ at the beginning of this zone, before dropping to ca. $80 \%$ in the second part. The zone is dominated by Pinus sylvestristype, with up to $65 \%$ of the pollen sum, as well as Betula with ca. $20 \%$. Also, other boreal and montane tree pollen is present, specifically Pinus cembra, Larix-type and Picea. Cold, steppic taxa like Juniperus-type, Artemisia and Chenopodiaceae show distinct pollen peaks in the second part of the zone, when AP declines (ca. 12,600-11,800 cal вР). Spores of the coprophilous fungi Sporormiella are present, albeit in low numbers. Arboreal macrofossils and stomata document the local presence of Pinus sylvestris, tree Betula (B. pubescens or B. pendula), tree Alnus (A. glutinosa or A. incana), Larix decidua and $B$. nana. Charcoal concentration and influx show a marked peak at the beginning of the zone but then decline to relatively low values, suggesting a gradually decreasing regional fire activity. The marked increase in AP, as well as the first trees documented with macrofossils around 13,450 cal $\mathrm{BP}$, indicate an expansion of closed, boreal forest in the region. The marked decrease in AP and an increase of steppic elements between 12,600 and $11,800 \mathrm{cal}$ BP points to a reversal to open forest steppe.

SVI-3 (11,800-10,800 cal вP): AP rises again to ca. $90 \%$ and stays at this level. Notable is the marked increase of Betula pollen to $40-55 \%$, some of the highest values of the record. This zone has the first continuous presence (empirical limit) of temperate taxa such as Ulmus, Fraxinus, Corylus and Quercus, although the latter three in low values. We did not analyze any macrofossil samples in this zone due to the low sampling resolution. Microscopic charcoal concentration and influx gradually increase during SVI-3 with a marked peak at ca. 11,380 cal BP. The results indicate closed forest with temperate trees such as Ulmus expanding in the surroundings of Lake Svityaz. Concomitantly, regional fire activity gradually increased.

SVI-4 (10,800-9,550 cal вP): Tree pollen stays high at ca. $90 \%$. Betula gradually decreases to ca. $25 \%$, whereas several temperate taxa such as Ulmus, Fraxinus, Quercus and Corylus increase, the latter rapidly and massively (rational limit). Tilia and A. glutinosa-type reach their empirical limit and are continuously present. Microscopic charcoal concentration and influx still increase with another marked peak at ca. 10,000 cal вр. Temperate tree pollen suggests that forest composition changed to a mixed deciduous forest, although with abundant boreal elements such as $P$. sylvestris and Betula. Forest fire activity reached a temporary maximum that was regained only during the past 500 years.

SVI-5 (9,550-8,050 cal вP): AP stabilizes at very high values (>90\%), mostly consisting of P. sylvestris-type, Betula, A. glutinosa-type and Corylus. Pollen of temperate 

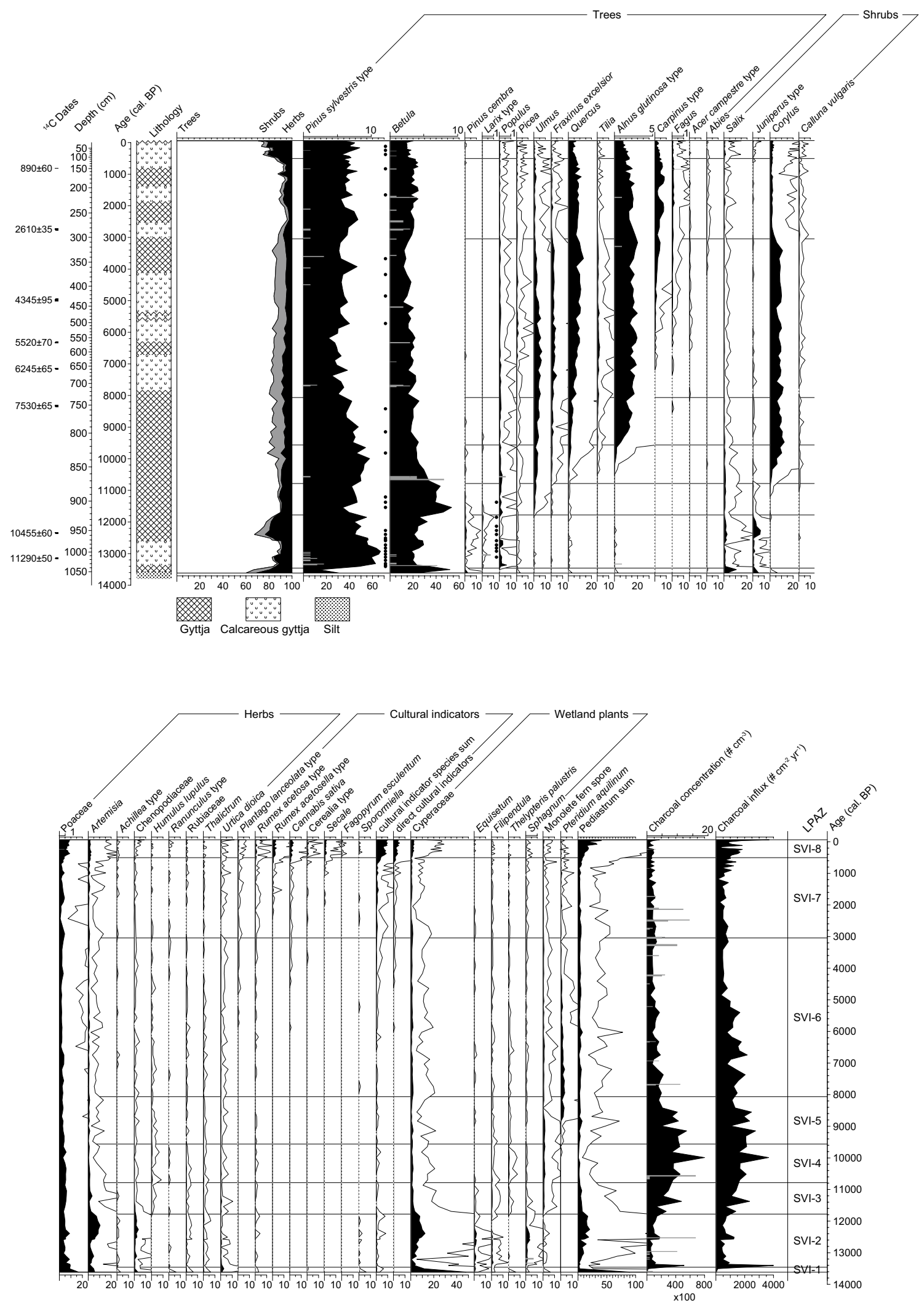

Fig. 3 Combined pollen and macrofossil diagram of selected taxa, including lithology, spores, stomata and microscopic charcoal concentration and influx. Direct cultural indicators include only crops, i.e. Cannabis sativa and cereals. LPAZ local pollen assemblage zone.
Empty curves show $10 \times$ exaggeration. Grey bars indicate total macrofossil concentrations (for $8 \mathrm{~cm}^{3}$ ) on the scale given at the top of the diagram. Black dots show presence of stomata 
taxa such as Ulmus, Quercus and Tilia is still increasing, whereas $P$. sylvestris-type is gradually decreasing to ca. 40\%. A. glutinosa-type shows a drastic increase to ca. $20 \%$. Pteridium aquilinum reaches the empirical limit and markedly increases after ca. 8,800 cal вP. Microscopic charcoal concentration and influx are still very high at the beginning of this zone, before dropping at the end, suggesting that fire activity remained high, only to decrease at ca. 8,200 cal вр. In general, vegetation structure and composition remained comparable to that of the previous zone, with the difference that the mass expansion of A. glutinosa-type most likely points to the establishment of alder carr vegetation around the edge of the lake and in marshy areas in the region.

SVI-6 (8,050-3,050 cal вP): Throughout the zone, AP remains consistently very high $(>90 \%)$. All temperate tree taxa show an optimum with the highest values in this zone. Carpinus-type, Acer and Fagus show the first continuous presence at ca. 7,200 and 6,000 cal BP respectively, the latter after its first appearance around 8,400 cal BP. Cultural pollen indicators, such as Plantago lanceolata-type, Cannabis sativa and Cerealia-type occur for the first time after ca. $5,800 \mathrm{cal}$ BP, although only intermittently or with very low values. Macrofossils and stomata document the local presence of P. sylvestris, Betula and Alnus. Microscopic charcoal concentrations and influx gradually decrease, suggesting declining fire activity. Closed temperate-continental forests dominated by Quercus, Ulmus, Fraxinus excelsior, Tilia, Corylus avellana and $P$. sylvestris surrounded Lake Svityaz until ca. 6,000 cal BP. Subsequently, Carpinus betulus and oceanic trees such as Fagus sylvatica and after 4,000 cal BP also Abies alba expanded. Very low and fragmentary occurrences of anthropogenic pollen indicators suggest weak farming activity in the area but with no discernible impact on the forest vegetation.

SVI-7 (3,050-500 cal вP): AP shows distinct fluctuations but stays generally above $90 \%$. Several temperate tree species such as Ulmus, Fraxinus, Tilia and Corylus show strong decreases in pollen percentages at the beginning of this zone. On the other hand other deciduous taxa increase such as Carpinus-type and Fagus or stay at high values (e.g. Quercus and A. glutinosa-type). The local presence of $F$. sylvatica near Lake Svityaz is documented by a single budscale in the macrofossil record. Cultural pollen indicators such as Cannabis sativa, Rumex acetosella-type and $P$. lanceolata-type are continuously present but remain at low values. However, pollen of crops such as Cerealia-type and Secale occur only intermittently. Microscopic charcoal concentration and influx remain relatively low, but macroscopic charcoal concentrations show very high peaks. Pollen and charcoal analyses indicate some small scale, short-lived, anthropogenic forest openings and a reduction of disturbance-sensitive and/or light-demanding temperate trees (Tilia, Fraxinus excelsior, Acer, Ulmus) and shrubs (Corylus avellana) in the forests surrounding the lake, while the rather disturbance-resistant Quercus, C. betulus, F. sylvatica and A. glutinosa remained fairly stable or even expanded.

SVI-8 (500 cal BP-present): At the beginning of this zone, AP drastically decreases to ca. $80 \%$, whereas herbs (NAP) increase. All tree taxa were equally affected, while light-demanding shrubs (e.g. Salix, Juniperus type, Corylus) expanded. Cultural pollen indicators such as Rumex acetosella-type, Cannabis sativa, Cerealia-type and Secale, as well as Poaceae show marked increases. The alga Pediastrum increases to its highest values at the end of the record. Microscopic charcoal influx increases, whereas its concentration remains low. The decrease in AP and the increase in anthropogenic pollen indicators points to large-scale forest openings for agriculture, leading to a higher nutrient input into the lake. The last 500 years of the record documents the establishment of the present-day cultural landscape, characterized by a mosaic of forest, marshes and agricultural fields.

\section{Ordination and biodiversity}

PCA axis 1 explains $54 \%$ of the variance in the pollen data and shows a climatic gradient, with temperate taxa such as Quercus, Fraxinus excelsior, A. glutinosa-type, Corylus, Ulmus and Tilia having low axis 1 scores, whereas boreal and steppic taxa such as Pinus cembra, Juniperus-type, Betula, Artemisia, Poaceae and Chenopodiaceae have high axis 1 scores (Fig. 4). PCA axis 2 explains $15 \%$ of the variance in the data and is related to anthropogenic activity with human pollen indicators such as P. lanceolata-type, Cannabis sativa, $R$. acetosella-type and Secale having high scores and trees such as Ulmus, Corylus, Fraxinus, Tilia and Betula having low scores. The low scores of the trees Carpinus-type, Fagus and Abies are explained by their late Holocene expansion (LPAZ SVI-7), when human impact also increased.

Both palynological richness (PRI) and evennessdetrended palynological richness (DE-PRI) show no clear trend throughout the record, except for the last 1,000 years when both indices markedly increase, to reach the highest diversity in the most recent samples (Fig. 5). Palynological evenness (PIE) on the other hand shows large fluctuations at the beginning of the record, with a tendency to uneven conditions during periods of Pinus dominance (ca. 13,500-12,600 cal вP and 11,600-10,000 cal вP), before gradually increasing and stabilizing at high values after ca. 8,000 cal BP. 


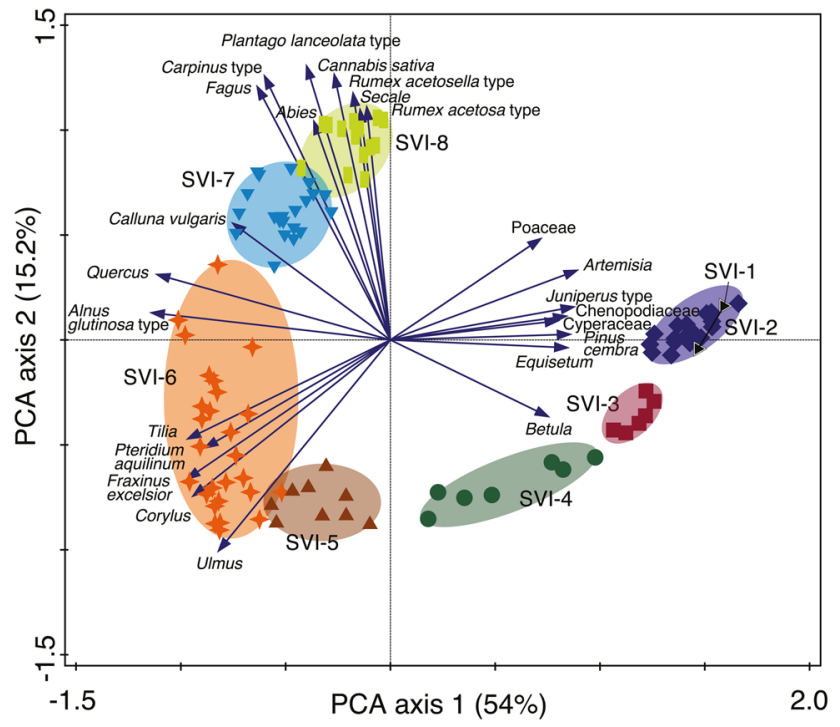

Fig. 4 PCA biplot showing species and sample scores of the Lake Svityaz pollen record. PCA axis 1 represents a climatic gradient from temperate arboreal taxa with low scores to boreal and steppic taxa with high scores. PCA axis 2 indicates a gradient of anthropogenic disturbance, with human pollen indicators and taxa expanding in the Late Holocene having high scores and taxa from closed natural forest with low scores. The sample groups are based on the statistically significant pollen zones, showing a transition from open, steppic landscapes to closed forest and on to the present-day agricultural landscape

\section{Discussion}

\section{Climatic drivers of vegetation dynamics}

The lithology (inorganic silt) and pollen analysis (NAP $>20 \%$ ) of the basal sediments of Lake Svityaz suggest that the record may extend to the Bølling or even Oldest Dryas prior to ca. 14,700 cal вр (van Raden et al. 2013). Unfortunately, we could not confirm this with radiocarbon dating, since we did not find any terrestrial macrofossils suitable for dating in this part of the sediment core. Nevertheless, such an old age would agree well with the onset of sediment accumulation in other lakes in the area. Both Lake Łukie and Perespilno in the Polish Polesie and Lake Słone in the Lublin Upland have been dated back to the Late Glacial (Bałaga 2004; Kulesza et al. 2011; Zawiska et al. 2015). The lithological change to organic gyttja at $1,050 \mathrm{~cm}$ in our core (tentatively dated to ca. 13,400 cal вP) coincides with a drastic increase in AP and the first occurrence of terrestrial macrofossils, indicating rapid forest expansion during the Bølling-Allerød interstadial (14,685-12,650 cal BP). At the beginning of the interstadial, temperatures increased by $3-6{ }^{\circ} \mathrm{C}$ within a century in Central Europe (Brooks and Heiri 2013; von Grafenstein et al. 2013; Heiri et al. 2014), leading to large-scale reorganization of terrestrial and aquatic ecosystems (e.g. Ammann et al. 2013; Feurdean et al. 2014; Zawiska et al. 2015). At Lake Svityaz, the pronounced warming at the beginning of the Bølling gradually led to the establishment of boreal forest dominated by $P$. sylvestris and Betula at ca. 13,450 cal BP. Interestingly, P. cembra and Larix decidua were also locally present during this period, as documented by the continuous presence of pollen as well as stomata and a single needle in the case of L. decidua. This suggests a close proximity to refugia where these species persisted during the coldest periods of the Last Glacial Maximum (LGM). Indeed, pollen and macrofossil findings indicate that the closest refugia were located in the forelands of the Carpathians (Lang 1994; Wagner et al. 2015), ca. $300 \mathrm{~km}$ to the south. However, given that our site was unglaciated, we cannot exclude that these very cold-tolerant trees survived the LGM locally in sheltered micro-habitats, where water availability was sufficient for tree growth. During the Late Glacial, L. decidua and P. cembra expanded northwards into the Central European lowlands (Lang 1994; Wagner et al. 2015). At present, the closest populations of $P$. cembra are situated in isolated high-elevation areas in the western Carpathians (Caudullo and de Rigo 2016). The present-day range of $L$. decidua also includes the Carpathians as well as the southeastern Polish lowlands (Da Ronch et al. 2016).

During the Younger Dryas cold period (12,650-11,700 cal вP; Engels et al. 2016) forests became more open around Lake Svityaz and steppic taxa increased, leading to the establishment of a forest-steppe. Vegetation-independent climate reconstructions in the region indicate an abrupt cooling of $1-4{ }^{\circ} \mathrm{C}$ in the summer months (Płóciennik et al. 2011; Heiri et al. 2014). The opening of the forests and the expansion of steppic elements can probably also be attributed to drier and more continental conditions (Pawłowski et al. 2015). With the beginning of the Holocene, forests closed again and the species composition gradually changed from a boreal forest dominated by Betula and P. sylvestris to mixed temperate deciduous forest dominated by Quercus, Corylus, Tilia and Ulmus. This drastic change in vegetation structure and composition can be attributed to a rapid warming of ca. $2-4{ }^{\circ} \mathrm{C}$ during the Younger Dryas-Holocene transition (Płóciennik et al. 2011; Feurdean et al. 2014; Heiri et al. 2014; Tóth et al. 2015; Hájková et al. 2016). The remarkable agreement between the chironomid-inferred July temperatures from the Baltic region (Heiri et al. 2014) and the tree pollen percentages at Lake Svityaz during the Younger Dryas (Fig. 5), indicate a strong impact of climate change on vegetation.

The first temperate tree to expand in the study area was Ulmus at ca. 11,800 cal BP, right at the end of the Younger Dryas. Its mass expansion was accomplished within a few centuries. This is remarkable since other temperate trees such as Quercus, Tilia or Corylus, expanded only ca. 500-1,000 years later in the area, although some were 
Fig. 5 Comparison of biotic proxies from Lake Svityaz with insolation and regional climate reconstructions: a Summary diagram of the pollen analysis showing total tree, shrub and herb pollen percentages; $\mathbf{b}$ pollen influx (grains $\mathrm{cm}^{-2} \mathrm{year}^{-1}$ ) of Ulmus, Tilia and the sum of direct human pollen indicators; c sample scores of PCA axes 1 and 2 , respectively representing climatic and anthropogenic gradients of vegetation change; d palynological richness (PRI), evenness-detrended palynological richness (DE-PRI) and evenness of the Lake Svityaz pollen assemblage as biodiversity measures; e microscopic charcoal influx (black curve) and macroscopic charcoal concentrations (grey bars); f July (red) and January (blue) insolation at $51^{\circ} \mathrm{N}$ (Laskar et al. 2004); $\mathbf{g}$ chironomid-inferred July temperatures at sea level from the Baltic region (Heiri et al. 2014), Hypkana in eastern Slovakia (Hájková et al. 2016) and Tăul dintre Brazi, in the southern Carpathians of Romania (Tóth et al. 2015); and h) $\delta^{18} \mathrm{O}$ from the Scărişoara Ice Cave in the Apuseni Mountains as a proxy for autumn through early winter temperatures (Perșoiu et al. 2017)
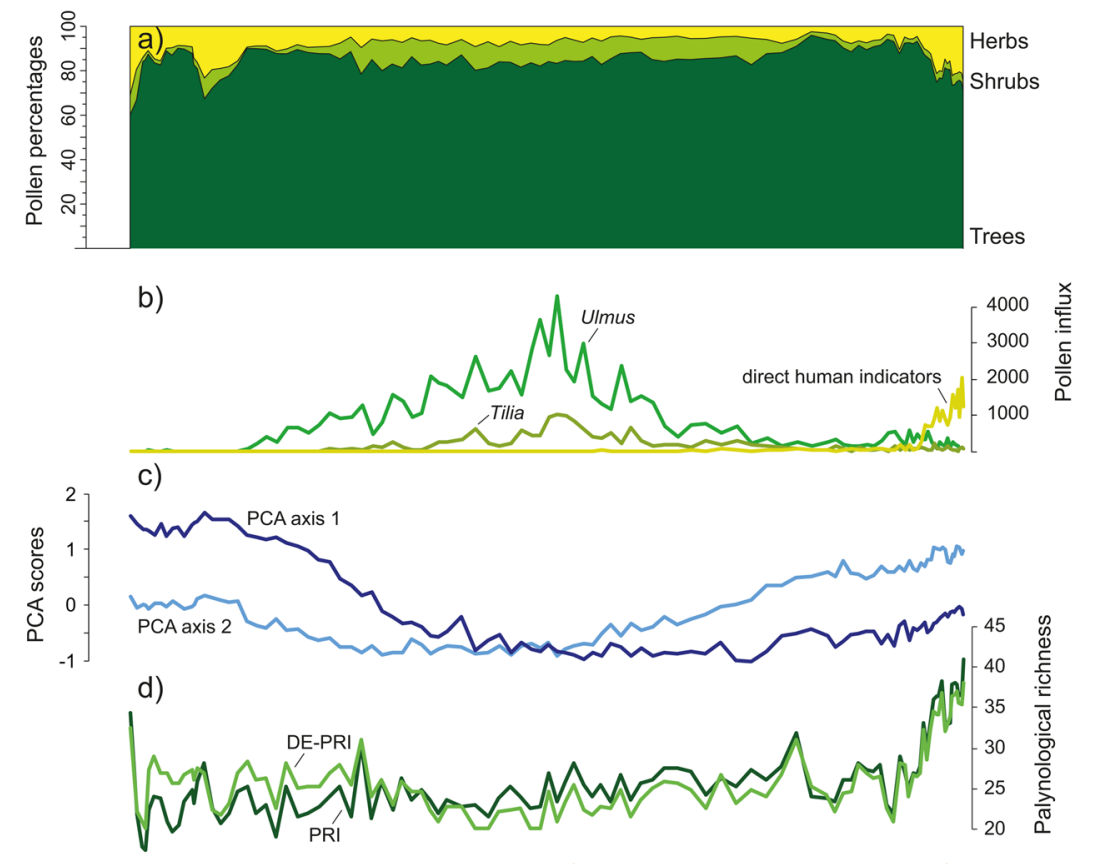

c)
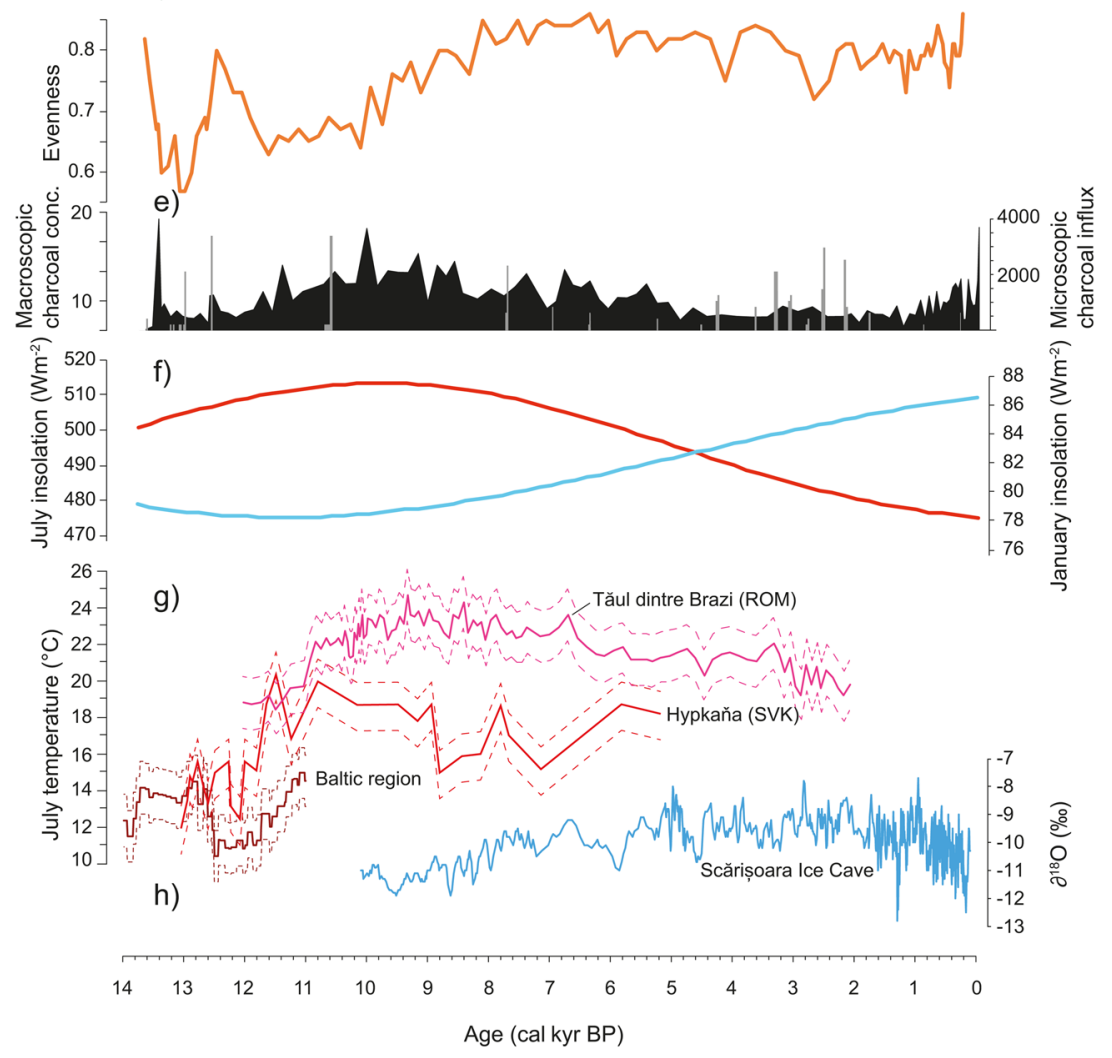

possibly locally present since the onset of the Holocene (e.g. empirical limit of Quercus at ca. 11,800 cal вP). Indeed, a recent study from Luka in the Dniestr Valley, Western Ukraine, found evidence for the local presence of Ulmus during the Late Younger Dryas (Kołaczek et al. 2018), whereas in the southern Carpathians, Ulmus was already locally present earlier (Feurdean et al. 2012), suggesting close proximity to a glacial refugium. From its refugium close to the southern Carpathians, Ulmus was apparently able to rapidly move northwards, possibly circumventing the Carpathian mountain range on the eastern side using river valleys such as the Dniestr as corridors (Kołaczek et al. 2018). 
After ca. 10,800 cal BP the boreo-nemoral forest around Lake Svityaz with few temperate elements (Ulmus and likely also Fraxinus, Quercus and Corylus in low abundances) was progressively replaced by mixed-deciduous temperate forest characterized by Quercus, Ulmus, Tilia, Corylus and Fraxinus. Our ordination analysis identifies this shift in forest types as the most important vegetation change at Lake Svityaz in the last 14,000 years. PCA axis 1 scores over time show that the shift from boreo-nemoral to mixed temperate forest took place over a very long period of 3,000 years from ca. 11,000-8,000 cal BP (with an acceleration at 10,000 cal BP; Fig. 5). Climate reconstructions indicate that summer temperatures during the Early Holocene in eastern Central Europe were slightly warmer than today (Feurdean et al. 2014; Tóth et al. 2015; Hájková et al. 2016), mainly in response to a high summer insolation (Fig. 5). Pollen percentages but also influx values show the highest abundance of temperate trees such as Ulmus, Tilia and Quercus between 7,000 and 6,000 cal BP (Figs. 3 and 5).

\section{Climatic and biotic drivers of fire regimes}

The steady increase of regional fire activity during the Early Holocene mirrors the summer insolation curve (Fig. 5), indicating that fire regimes were directly controlled by summer temperature and/or precipitation, which in turn also led to high forest productivity and therefore fuel availability. Indeed, the highest fire activity during ca. 10,500-8,500 cal BP coincides with the highest reconstructed summer temperatures during the Holocene in Central Europe (Tóth et al. 2015; Hájková et al. 2016). Interestingly, high fire activity did not prevent the establishment and population expansion of fire sensitive taxa such as Tilia and Ulmus in the region. This apparent discrepancy has also been noted in other studies in the larger surroundings, the Carpathians and the Dniestr valley (Hájková et al. 2016; Kołaczek et al. 2018, 2020), where it has been attributed to landscape heterogeneity, with fire-sensitive taxa occurring in wetter, less fireprone habitats (Kołaczek et al. 2020). Therefore, fires around Lake Svityaz were likely restricted to drier areas on sandy soils dominated by $P$. sylvestris and did not affect vegetation in the wetter areas. In addition, charcoal influx indicates that fire activity was very modest compared to fire-prone southern Europe, likely not exceeding the tolerance of firesensitive species (maximum Holocene charcoal influx peak of 4,000 particles $\mathrm{cm}^{-2}$ year $^{-1}$ vs. peaks of 40,000-400,000 particles $\mathrm{cm}^{-2}$ year $^{-1}$ in southern Europe; Tinner et al. 2005, 2009, 2016). Regional fire activity slightly decreased after ca. 8,200 cal BP with decreasing summer insolation and a change to more oceanic conditions with milder winters (Perșoiu et al. 2017). Fire activity further declined after the regional expansion of broad-leaved deciduous forests dominated by Carpinus betulus, possibly even with admixed
Fagus sylvatica, suggesting a biotic control of fire regimes. Recent studies from Central and Eastern Europe have argued that expansion of broad-leaved deciduous forest can lead to fire suppression due to lower flammability, higher forest density and moister microclimate (Feurdean et al. 2017; Bobek et al. 2019; Carter et al. 2020). However, it is difficult to disentangle climatic and biotic drivers of fire regimes at our site, since the expansion of mesophilous beech forests in Central Europe has been attributed to cool and wet conditions (Tinner and Lotter 2006; Giesecke et al. 2011) that in turn also have an effect on fuel flammability and fire spread. Consistently, the $F$. sylvatica expansion around 5,900 cal BP at Lake Svityaz falls in the cool and wet period from ca. 6,100 to 5,650 cal BP (Central European cold phase CE-5, see Haas et al. 1998; Heiri et al. 2004), when the tree expanded also elsewhere in eastern Central Europe (Lang 1994; Tinner and Lotter 2006).

\section{Human impact on pristine forests}

Mesolithic people of the Komornicka and Janisławicka cultures were already present in the Polesie area since the Late Glacial, as evidenced by findings of flint tools (Bałaga 2007a). However, the impact of these hunter-gatherers on the natural vegetation was only marginal. First farming communities connected to sites of the Volynskaya Neolithic culture and Linear Pottery Culture (LBK) established in the second part of the sixth millennium $\mathrm{BC}$ in the region (Kotova 2003). Earliest archaeological findings of LBK from southeastern Poland and northwestern Ukraine have been dated to 5300-4800 ВС or 7,300-6,800 cal BP, indicating a rapid eastward spread of the LBK (Kotova 2003; Motuzaité Matuzevičiūtè and Telizhenko 2016; CzekajZastawny et al. 2020). In the northwestern Pontic region of the Ukrainian steppe, there is even earlier evidence for plant and animal domestication that has been attributed to the Bug-Dniestr culture, dated to the second half of the seventh millennium вс (ca. 8,200-8,000 cal вP; Telegin et al. 2003; Vinogradova and Kiosak 2017). There is no evidence of these earliest agricultural activities in the Lake Svityaz record, probably due to very low population densities and extremely localized impact on the vegetation. The first signs of agricultural activity by Neolithic societies in our record date to ca. 5,900-5,700 cal BP. This is evidenced by the first occurrence of pollen of P. lanceolata type and Cannabis sativa, two cultural indicators of agricultural fields (Behre 1981). This timing agrees well with other palaeoecological studies in the Belarusian Polesie region that date the beginning of the Neolithic based on palynological records to ca. 6,600-6,000 cal BP (Zernitskaya and Mikhailov 2009). During the time of the earliest palynological evidence of agricultural activity around Lake Svityaz (5,900-5,700 cal вр), people of the Lublin-Volynian Eneolithic culture settled in 
this region (Zakościelna and Starkova 2018). These people used more sophisticated agricultural practices than the LBK and focused on the cultivation of grain crops on the plateau. They also used fire as a tool of agricultural technology, not only to clear forests, but also to prevent scrub encroachment (Kadrow 2016). Nevertheless, our pollen record from Lake Svityaz indicates that population density was still very low, reaffirming the marginal nature of the area. However, the onset of agriculture in the region broadly coincides with both a population decline of disturbance-sensitive tree species such as Tilia and Ulmus around 6,500-5,800 cal вP and the regional establishment of $C$. betulus and $F$. sylvatica at 7,000 cal вP and 5,900 cal вP, respectively (empirical limits; Figs. 3 and 5). Both the decline of Tilia and Ulmus as well as the dominance of $F$. sylvatica and $C$. betulus in Central European forests have previously been attributed to human disturbance (Küster 1997; Ralska-Jasiewiczowa et al. 2003; Thöle et al. 2016; Rey et al. 2019). However, this does not exclude a prominent role of climatic change e.g. as resulting from decadal-scale oscillations or due to the millennialscale effects of decreasing summer insolation (Fig. 5), given that the latter resulted in a shift to more oceanic conditions during the mid-Holocene. Most likely, the slight, temporary declines of Tilia and Ulmus at 6,500-5,800 cal вр were a result of competition with the more shade-tolerant $C$. betulus and later F. sylvativa, and not directly caused by human impact. At the end of the mid-Holocene, around ca. 5,000 cal вр, forests were composed of $C$. betulus, $F$. sylvatica, Acer, P. sylvestris, Betula, Quercus, Ulmus, Tilia, Fraxinus excelsior and Corylus avellana, thus displaying a very high diversity, which is also reflected in high evenness values (Fig. 5).

At Lake Svityaz, F. sylvatica reached the easternmost limit of its maximum range. Although currently the tree is not present anymore in the area (Houston Durrant et al. 2016), the occurrence of a single bud scale in the macrofossil record as well as the continuous curve in the pollen diagram points to its local presence around our study site. Fagus pollen also reaches the empirical limit in other sites in the area, such as at ca. 6,000 cal вP at Peshanoe and nearby Lake Oltush in southern Belarus (Zernitskaya 1991), during the mid-Holocene at several lakes in the Polish Polesie (Bałaga 2004, 2007b), or around 3,600 cal BP at Makovich in the Western Ukraine (Artushenko 1957). Unlike C. betulus, which is more tolerant of late frosts and an important component of the mixed temperate forests in the area, $F$. sylvatica was most likely only present in low numbers. Since the trees growing at Lake Svityaz represented the outermost edge of its range, they were most likely highly stressed, so that small changes in climate, such as the cooling during the Little Ice Age (Büntgen et al. 2011; Perşoiu et al. 2017) or increasing disturbance, might have been enough to lead to its local extinction.
With the intensification of land use in the Late Bronze Age (3,400 cal вр) linked to the Trzciniec Bronze culture (Czebreszuk et al. 1998), some forest trees such as Ulmus, Tilia, Fraxinus and Corylus abruptly declined in the surrounding area. High concentrations of macroscopic charcoal and the first presence of Cerealia-type pollen indicate that fire was used to create local, small scale forest openings for agriculture, likely close to the lake shore. The decline of Corylus is surprising, since it can resprout quickly, thrives after fire disturbance (Tinner et al. 1999) and is only affected by very frequent fires (Delarze et al. 1992). This sudden decline, which is accompanied by a decline in Fraxinus and is also evident in pollen influx, may be attributed to the further local expansion of the shade-tolerant $C$. betulus and $F$. sylvatica in the forest. A similar pattern has been observed at other lakes in the Polish Polesie and northern Poland, indicating regional-scale changes in the forest composition around 3,000 cal вP (Ralska-Jasiewiczowa et al. 2003; Bałaga 2007a, b; Lamentowicz et al. 2019). At the same time, a northward expansion of forest-steppe associated with climate aridification has been recorded in the European part of Russia (Spiridonova and Lavrushin 1997). Such synchronous vegetation changes over large spatial scales are commonly attributed to a climatic driver, since human disturbance would likely produce a more heterogeneous signal (Ralska-Jasiewiczowa et al. 2003; Jalut et al. 2009). However, climate can also trigger societal and demographic changes that lead to broad-scale synchronous patterns of human activity (Rey et al. 2019; Walsh et al. 2019). Even though human impact was still relatively low, the creation of open areas and increased disturbance led to a marked increase in palynological diversity (Fig. 5). Forests quickly recovered from local anthropogenic activities during the Late Bronze Age and overall regional forest cover was still very high.

During the Iron Age, around 2,400 cal вP, tree pollen even reached its highest values of the entire record (96\%), whereas cultural pollen indicators and Poaceae markedly declined, indicating local land abandonment and closed, dense forests around the site, possibly in response to a shortlived cool and humid period (Haas et al. 1998; Büntgen et al. 2011). Later on, still during the Iron Age, there is again evidence for small-scale forest openings and agricultural activity around Lake Svityaz, as documented by a decline in tree abundance of $P$. sylvestris or $C$. betulus, and an increase in cultural pollen indicators, the occurrence of Secale and other cereal pollen (Fig. 3) and evidence for local fires. Increasing human impact at ca. 2,000 cal BP coincides with the southward expansion of Gothic tribes in the first and second century AD (Stolarek et al. 2019). During the subsequent migration period, land use pressure declined and forests quickly became closed again. Large-scale forest clearing and the establishment of the present-day cultural landscape 
only occurred during the last 500 years. This is reflected in a drastic increase of cultural pollen indicators such as Cerealia and Secale and open land taxa (e.g. Poaceae; Fig. 3), as well as in palynological richness (Fig. 5). Our data indicates that people preferentially cleared the broad-leaved deciduous forest and not drier and/or sandier areas dominated by $P$. sylvestris, to create fields mainly for arable farming with only little animal husbandry.

Overall, except for the last few 100 years of the record, human impact on the natural landscape was very low. Indeed, PCA axis 2, which reflects the gradient of natural forests to anthropogenic environments, only explains $15 \%$ of the variation in the dataset, in contrast to PCA axis 1 that explains $54 \%$ and likely reflects the climate-driven change from boreal to temperate ecosystems (Fig. 4). The creation of a mosaic of forests, pastures and arable fields in recent history has led to the unprecedented rise of palynologically inferred species richness in our record (Fig. 5). Tree species diversity, on the other hand, has steadily been decreasing since the Bronze Age, with the decline of many disturbancesensitive taxa such as Tilia, Ulmus and Acer. However, the persistence of these diverse, mixed temperate-continental forests until well into the Late Holocene is remarkable. Central European sites situated on more fertile soils where Neolithic settlements are documented show a rapid decline of these disturbance-sensitive taxa already during the midHolocene, i.e. after ca. 6,500 cal вр (Rösch 1992; Kalis et al. 2003; Thöle et al. 2016; Rey et al. 2019), indicating that the impoverishment of the Central European temperate forest was primarily driven by anthropogenic disturbance.

\section{Conclusions}

Our study shows that the area surrounding Lake Svityaz was always very marginal for land use compared to other regions of Europe, where intense agricultural activity was already causing dramatic forest vegetation shifts during the Neolithic (Fyfe et al. 2015; Roberts et al. 2018; Whitlock et al. 2018). While vegetation structure (e.g. forest density/ openness) remained almost unaltered until ca. 500 years ago, forest composition changed 3,000-2,500 years ago, likely in response to intensified human impact. Recent anthropogenic disturbance during historic times (i.e. the last 500 years) led to an increase in overall plant diversity by creating new habitats, introducing new species, such as cultivated plants and weeds, and increasing ecosystem heterogeneity. For the greater part of the Holocene (ca. 10,000-3,000 cal BP), mixed temperate-continental forest dominated the area, with higher abundances than at present of light-loving temperate trees such as Tilia, Ulmus, Acer or Corylus. The longer persistence of such highly diverse mixed forest in an agriculturally marginal area indicates that human disturbance was a major driver of Central European forest dynamics in more fertile regions. The use of fire to clear forest for arable land, browsing by livestock and selective logging led to a decline of disturbance-sensitive taxa such as Tilia, Ulmus and Acer.

Our record clearly indicates that at Lake Svityaz, climate was the main driver of vegetation and fire dynamics until the Late Holocene. Slightly higher than present temperatures during the Holocene Thermal Maximum, possibly in combination with more flammable forests, led to a markedly higher fire activity in the region under near-natural conditions. This implies that warmer and drier conditions, as projected with future climate change, could significantly increase the risk of forest fires in the region. Indeed, the current climate warming has led to devastating fires in the temperate-continental forests of Ukraine, Belarus and Russia in recent years, which is of particular concern due to the presence of forests that are highly contaminated by radioactive fallout after the explosion of the Chernobyl nuclear power plant in 1986 (Evangeliou et al. 2015). The situation is further exacerbated by the extensive plantation of flammable pine in the region since the 1950 s, which now cover more than $60 \%$ of the forested area in the Ukrainian Polesie alone (Moroz et al. 2020). A return to more mixed deciduous forests including $C$. betulus, Tilia, Ulmus, Acer and Quercus could reduce the fire risk due to lower flammability, which would be an important step toward climate change mitigation.

Supplementary Information The online version contains supplementary material available at https://doi.org/10.1007/s00334-021-00844-z.

Acknowledgements This project has been funded by the Swiss National Science Foundation within the framework of the SCOPES funding scheme (Grant No. SNF-128248). We would also like to thank Stéphanie Samartin, V. Nemiroff and Willi Tanner for help during fieldwork and are grateful for the constructive comments of two anonymous reviewers.

Author contributions WT, SM and NK contributed to the conception and design of the study. Material preparation, data collection and analysis were performed by EG, JFNvL, SB, RI, WOvdK and CS. A first draft of the manuscript was written by CS. All authors commented on previous versions of the manuscript and read and approved the final version.

Funding Open Access funding provided by Universität Bern.

Data availability All data is currently stored in the Alpine Pollen Database (ALPADABA) and will be made publicly available on the European Pollen Database (EPD, https://www.europeanpollendataba se.net) and Neotoma (https://www.neotomadb.org) upon publication of this article.

\section{Declarations}

Conflict of interest The authors have no conflict of interest to declare that are relevant to the content of this article. 
Open Access This article is licensed under a Creative Commons Attribution 4.0 International License, which permits use, sharing, adaptation, distribution and reproduction in any medium or format, as long as you give appropriate credit to the original author(s) and the source, provide a link to the Creative Commons licence, and indicate if changes were made. The images or other third party material in this article are included in the article's Creative Commons licence, unless indicated otherwise in a credit line to the material. If material is not included in the article's Creative Commons licence and your intended use is not permitted by statutory regulation or exceeds the permitted use, you will need to obtain permission directly from the copyright holder. To view a copy of this licence, visit http://creativecommons.org/licenses/by/4.0/.

\section{References}

Ammann B, van Raden UJ, Schwander J et al (2013) Responses to rapid warming at Termination 1a at Gerzensee (Central Europe): primary succession, albedo, soils, lake development, and ecological interactions. Palaeogeogr Palaeoclimatol Palaeoecol 391(Part B):111-131. https://doi.org/10.1016/j.palaeo.2013.11.009

Ammerman AJ, Cavalli-Sforza LL (1971) Measuring the rate of spread of early farming in Europe. Man 6:674-688. https://doi.org/10. 2307/2799190

Artushenko AT (1957) History of the development of the West Ukrainian Polessye vegetation in Late Glacial and Post-Glacial times on the basis of the palynological studies. Ukrain'skyi Botanichnyi Zhurnal 14:12-29

Bałaga K (2004) Changes of vegetation in Lake Perespilno environs (Lublin Polesie) in the Late Glacial and Holocene. Acta Palaeobot 44:147-166

Bałaga K (2007a) Transformation of Lake Ecosystem into Peat Bog and vegetation history based on Durne Bagno Mire (Lublin Polesie, E Poland). Geochronometria 29:23-43. https://doi.org/10.2478/ v10003-007-0033-y

Bałaga K (2007b) Changes in the natural environment recorded in the sediments of the Karaśne Lake-mire complex (Lublin Polesie, E Poland). Geochronometria 29:1-21. https://doi.org/10.2478/ v10003-007-0032-z

Behre K-E (1981) The interpretation of anthropogenic indicators in pollen diagrams. Pollen Spores 23:225-245

Bennett KD (1996) Determination of the number of zones in a biostratigraphical sequence. New Phytol 132:155-170

Betti L, Beyer RM, Jones ER et al (2020) Climate shaped how Neolithic farmers and European hunter-gatherers interacted after a major slowdown from 6,100 BCE to 4,500 BCE. Nat Hum Behav 4:1,004-1,010. https://doi.org/10.1038/s41562-020-0897-7

Beug H-J (2004) Leitfaden der Pollenbestimmung für Mitteleuropa und angrenzende Gebiete. Pfeil, München

Birks HJB, Gordon AD (1985) Numerical methods in quaternary pollen analysis. Academic Press, London

Birks HJB, Line JM (1992) The use of rarefaction analysis for estimating palynological richness from quaternary pollen-analytical data. Holocene 2:1-10. https://doi.org/10.1177/0959683692 00200101

Birks HJB, Tinner W (2016) European tree dynamics and invasions during the Quaternary. In: Krumm F, Vìtkovà L (eds) Introduced tree species in European forests: opportunities and challenges. European Forest Institute, Freiburg, pp 22-43

Blaauw M (2010) Methods and code for 'classical' age-modelling of radiocarbon sequences. Quat Geochronol 5:512-518

Bobek P, Svitavská Svobodová H, Werchan B et al (2018) Humaninduced changes in fire regime and subsequent alteration of the sandstone landscape of Northern Bohemia (Czech Republic).
Holocene 28:427-443. https://doi.org/10.1177/0959683617 729443

Bobek P, Svobodová-Svitavská H, Pokorný P et al (2019) Divergent fire history trajectories in Central European temperate forests revealed a pronounced influence of broadleaved trees on fire dynamics. Quat Sci Rev 222:105865. https://doi.org/10.1016/j. quascirev.2019.105865

Brooks SJ, Heiri O (2013) Response of chironomid assemblages to environmental change during the early Late-glacial at Gerzensee, Switzerland. Palaeogeogr Palaeoclimatol Palaeoecol 391(Part B):90-98. https://doi.org/10.1016/j.palaeo.2012.10. 022

Büntgen U, Tegel W, Nicolussi K et al (2011) 2500 years of european climate variability and human susceptibility. Science 331:578582. https://doi.org/10.1126/science. 1197175

Carter VA, Bobek P, Moravcová A et al (2020) The role of climatefuel feedbacks on Holocene biomass burning in upper-montane Carpathian forests. Glob Planet Chang 193:103264. https://doi. org/10.1016/j.gloplacha.2020.103264

Caudullo G, de Rigo D (2016) Pinus cembra in Europe: distribution, habitat, usage and threats. In: San-Miguel-Ayanz J, de Rigo D, Caudullo $\mathrm{G}$ et al (eds) European Atlas of forest tree species. Publication Office of the European Union, Luxembourg, pp 120-121

Colombaroli D, Tinner W (2013) Determining the long-term changes in biodiversity and provisioning services along a transect from Central Europe to the Mediterranean. Holocene 23:1625-1634

Colombaroli D, Beckmann M, van der Knaap WO, Curdy P, Tinner W (2013) Changes in biodiversity and vegetation composition in the central Swiss Alps during the transition from pristine forest to first farming. Divers Distrib 19:157-170

Czebreszuk J, Gorski J, Ignaczak M et al (1998) The Trzciniec area of the Early Bronze Age civilization: 1950-1200 BC. Adam Mickiewicz University Press, Poznań

Czekaj-Zastawny A, Rauba-Bukowska A, Kukułka A et al (2020) The earliest farming communities north of the Carpathians: the settlement at Gwoździec site 2. PLoS ONE 15:e0227008. https:// doi.org/10.1371/journal.pone.0227008

Da Ronch F, Caudullo G, Tinner W, de Rigo D (2016) Larix decidua and other larches in Europe: distribution, habitat, usage and threats. In: San-Miguel-Ayanz J, de Rigo D, Caudullo G et al (eds) European Atlas of forest tree species. Publication Office of the European Union, Luxembourg, pp 108-110

Delarze R, Caldelari D, Hainard P (1992) Effects of fire on forest dynamics in southern Switzerland. J Veg Sci 3:55-60. https:// doi.org/10.2307/3235998

Dobrowolski R, Ziółek M, Bałaga K, Melke J, Bogucki A (2010) Radiocarbon age and geochemistry of the infillings of small closed depressions from western Polesie (Poland Se, Ukraine Nw). Geochronometria 36:39-46. https://doi.org/10.2478/ v10003-010-0010-8

Dobrowolski R, Kulesza P, Łojek J, Pidek IA (2015) Origin and evolution of the Bezedna lake-mire complex in the Lublin area (East Poland): a case study for permafrost lakes in karstic regions. J Paleolimnol 53:191-213. https://doi.org/10.1007/ s10933-014-9818-y

Engels S, Brauer A, Buddelmeijer N et al (2016) Subdecadal-scale vegetation responses to a previously unknown late-Allerød climate fluctuation and Younger Dryas cooling at Lake Meerfelder Maar (Germany). J Quat Sci 31:741-752. https://doi.org/10.1002/jqs. 2900

Evangeliou N, Balkanski Y, Cozic A et al (2015) Fire evolution in the radioactive forests of Ukraine and Belarus: future risks for the population and the environment. Ecol Monogr 85:49-72. https:// doi.org/10.1890/14-1227.1

Feurdean A, Tămaş T, Tanţău I, Fărcaş S (2012) Elevational variation in regional vegetation responses to late-glacial climate changes 
in the Carpathians. J Biogeogr 39:258-271. https://doi.org/10. 1111/j.1365-2699.2011.02605.x

Feurdean A, Perşoiu A, Tanţău I et al (2014) Climate variability and associated vegetation response throughout Central and Eastern Europe (CEE) between 60 and $8 \mathrm{ka}$. Quat Sci Rev 106:206-224. https://doi.org/10.1016/j.quascirev.2014.06.003

Feurdean A, Veski S, Florescu G et al (2017) Broadleaf deciduous forest counterbalanced the direct effect of climate on Holocene fire regime in hemiboreal/boreal region (NE Europe). Quat Sci Rev 169:378-390. https://doi.org/10.1016/j.quascirev.2017.05. 024

Finsinger W, Tinner W (2005) Minimum count sums for charcoalconcentration estimates in pollen slides: accuracy and potential errors. Holocene 15:293-297

Finsinger W, Tinner W (2020) New insights on stomata analysis of European conifers 65 years after the pioneering study of Werner Trautmann (1953). Veget Hist Archaeobot 29:393-406. https://doi.org/10.1007/s00334-019-00754-1

Fyfe RM, Woodbridge J, Roberts N (2015) From forest to farmland: pollen-inferred land cover change across Europe using the pseudobiomization approach. Glob Chang Biol 21:1,1971,212. https://doi.org/10.1111/gcb.12776

Gassner S, Gobet E, Schwörer C et al (2020) 20,000 years of interactions between climate, vegetation and land use in Northern Greece. Veget Hist Archaeobot 29:75-90. https://doi.org/10. 1007/s00334-019-00734-5

Giesecke T, Bennett KD, Birks HJB et al (2011) The pace of Holocene vegetation change-testing for synchronous developments. Quat Sci Rev 30:2,805-2,814

Gobet E, Tinner W, Hochuli PA, van Leeuwen JFN, Ammann B (2003) Middle to Late Holocene vegetation history of the Upper Engadine (Swiss Alps): the role of man and fire. Veget Hist Archaeobot 12:143-163. https://doi.org/10.1007/ s00334-003-0017-4

Guilaine J (2018) A personal view of the neolithisation of the Western Mediterranean. Quat Int 470:211-225. https://doi.org/10.1016/j. quaint.2017.06.019

Haas JN, Richoz I, Tinner W, Wick L (1998) Synchronous Holocene climatic oscillations recorded on the Swiss Plateau and at timberline in the Alps. Holocene 8:301-309

Hájková P, Pařil P, Petr L et al (2016) A first chironomid-based summer temperature reconstruction (13-5 ka BP) around $49^{\circ} \mathrm{N}$ in inland Europe compared with local lake development. Quat Sci Rev 141:94-111. https://doi.org/10.1016/j.quascirev.2016.04.001

Heegaard E, Birks HJB, Telford RJ (2005) Relationships between calibrated ages and depth in stratigraphical sequences: an estimation procedure by mixed-effect regression. Holocene 15:612-618

Heiri O, Tinner W, Lotter AF (2004) Evidence for cooler European summers during periods of changing meltwater flux to the North Atlantic. Proc Natl Acad Sci USA 101:15,285-15,288

Heiri C, Bugmann H, Tinner W, Heiri O, Lischke H (2006) A modelbased reconstruction of Holocene treeline dynamics in the Central Swiss Alps. J Ecol 94:206-216

Heiri O, Brooks SJ, Renssen H et al (2014) Validation of climate model-inferred regional temperature change for late-glacial Europe. Nat Commun 5:4914. https://doi.org/10.1038/ncomm s5914

Henne PD, Elkin C, Colombaroli D et al (2013) Impacts of changing climate and land use on vegetation dynamics in a Mediterranean ecosystem: insights from paleoecology and dynamic modeling. Landsc Ecol 28:819-833

Hofmanová Z, Kreutzer S, Hellenthal G et al (2016) Early farmers from across Europe directly descended from Neolithic Aegeans. Proc Natl Acad Sci USA 113:6,886-6,891. https://doi.org/10.1073/ pnas. 1523951113
Houston Durrant T, de Rigo D, Caudullo G (2016) Fagus sylvatica in Europe: distribution, habitat, usage and threats. In: San-MiguelAyanz J, de Rigo D, Caudullo G et al (eds) European Atlas of Forest Tree Species. Publication Office of the European Union, Luxembourg, pp 94-95

Hurlbert SH (1971) The nonconcept of species diversity: a critique and alternative parameters. Ecology 52:577-586. https://doi. org/10.2307/1934145

Jalut G, Dedoubat JJ, Fontugne M, Otto T (2009) Holocene circumMediterranean vegetation changes: climate forcing and human impact. Quat Int 200:4-18. https://doi.org/10.1016/j.quaint. 2008.03.012

Kadrow S (2016) The dawn of the eneolithic in northern outskirts of the Late Danubian world on the turn of 5th and 4th Millennia BC. Stratum plus 2016:17-35

Kalis AJ, Merkt J, Wunderlich J (2003) Environmental changes during the Holocene climatic optimum in central Europe-human impact and natural causes. Quat Sci Rev 22:33-79. https://doi. org/10.1016/S0277-3791(02)00181-6

Kołaczek P, Gałka M, Apolinarska K et al (2018) A multi-proxy view of exceptionally early postglacial development of riparian woodlands with Ulmus in the Dniester River valley, western Ukraine. Rev Palaeobot Palynol 250:27-43. https://doi.org/10. 1016/j.revpalbo.2017.12.001

Kołaczek P, Margielewski W, Gałka M et al (2020) Towards the understanding the impact of fire on the lower montane forest in the Polish Western Carpathians during the Holocene. Quat Sci Rev 229:106137. https://doi.org/10.1016/j.quascirev.2019. 106137

Kotova NS (2003) Neolithization in Ukraine. British Archaeological Reports Series 1109. BAR Publishing, Oxford

Kotova N (2009) The Neolithization of Northern Black Sea area in the context of climate changes. Doc Praehist 36:159-174. https:// doi.org/10.4312/dp. 36.10

Kotsakis K (2014) Domesticating the periphery. Pharos 20:41-73

Kulesza P, Suchora M, Pidek IA, Alexandrowicz WP (2011) Chronology and directions of Late Glacial paleoenvironmental changes: A multi-proxy study on sediments of Lake Słone (SE Poland). Quat Int 238:89-106. https://doi.org/10.1016/j.quaint.2010.12. 024

Küster H (1997) The role of farming in the postglacial expansion of beech and hornbeam in the oak woodlands of central Europe. Holocene 7:239-242. https://doi.org/10.1177/095968369700700 213

Lambert C, Vidal M, Penaud A et al (2019) Palaeoenvironmental reconstructions during the Meso- to Neolithic transition (9.2-5.3 cal. ka вP) in Northwestern France: Palynological evidences. Holocene 29:380-402. https://doi.org/10.1177/0959683618816457

Lamentowicz M, Kołaczek P, Mauquoy D et al (2019) Always on the tipping point $-\mathrm{a}$ search for signals of past societies and related peatland ecosystem critical transitions during the last 6500 years in N Poland. Quat Sci Rev 225:105954. https://doi.org/10.1016/j. quascirev.2019.105954

Lang G (1994) Quartäre Vegetationsgeschichte Europas: Methoden und Ergebnisse. Fischer, Jena

Laskar J, Robutel P, Joutel F et al (2004) A long-term numerical solution for the insolation quantities of the Earth. Astron Astrophys 428:261-285. https://doi.org/10.1051/0004-6361:20041335

Legendre P, Birks HJB (2012) From classical to canonical ordination. In: Birks HJB, Lotter AF, Juggins S, Smol JP (eds) Tracking environmental change using lake sediments. Springer, Netherlands, pp 201-248

Meteostat (2021) Available at https://meteostat.net/en/station/12497. Accessed on 18 May 2021

Miras Y, Ejarque A, Orengo $\mathrm{H}$ et al (2010) Prehistoric impact on landscape and vegetation at high altitudes: an integrated 
palaeoecological and archaeological approach in the eastern Pyrenees (Perafita valley, Andorra). Plant Biosyst 144:924-939. https://doi.org/10.1080/11263504.2010.491980

Moore PD, Webb JA, Collinson ME (1991) Pollen analysis, 2nd edn. Blackwell Science, Oxford

Moroz VV, Nykytiuk YA, Nykytiuk PA, Kliuchevych MM, Komorna OM (2020) Carbon Absorption Ability of Pine Forest Plantations in the Ukrainian Polissya. Ukr J Ecol 10:249-255. https:// doi.org/10.15421/2020_91

Motuzaité Matuzevičiūtė G, Telizhenko S (2016) The first farmers of Ukraine: an archaeobotanical investigation and AMS dating of wheat grains from the Ratniv-2 site. Archaeol Litu 17:100-111

Odgaard BV (1999) Fossil pollen as a record of past biodiversity. J Biogeogr 26:7-17. https://doi.org/10.1046/j.1365-2699.1999. 00280.x

Oksanen J, Blanchet FG, Kindt R et al (2015) Vegan: community ecology package. Available at https://cran.r-project.org

Parker AG, Goudie AS, Anderson DE, Robinson MA, Bonsall C (2002) A review of the mid-Holocene elm decline in the British Isles. Prog Phys Geogr 26:1-45. https://doi.org/10.1191/ 0309133302pp323ra

Pawłowski D, Płóciennik M, Brooks SJ et al (2015) A multiproxy study of Younger Dryas and Early Holocene climatic conditions from the Grabia River paleo-oxbow lake (central Poland). Palaeogeogr Palaeoclimatol Palaeoecol 438:34-50. https://doi. org/10.1016/j.palaeo.2015.07.031

Peglar SM (1993) The mid-Holocene Ulmus decline at Diss Mere, Norfolk, UK: a year-by-year pollen stratigraphy from annual laminations. Holocene 3:1-13. https://doi.org/10.1177/09596 8369300300101

Perşoiu A, Onac BP, Wynn JG et al (2017) Holocene winter climate variability in Central and Eastern Europe. Sci Rep 7:1196. https://doi.org/10.1038/s41598-017-01397-w

Pinhasi R, Fort J, Ammerman AJ (2005) Tracing the origin and spread of agriculture in Europe. PLoS Biol 3:e410. https:// doi.org/10.1371/journal.pbio.0030410

Płóciennik M, Self A, Birks HJB, Brooks SJ (2011) Chironomidae (Insecta: Diptera) succession in Żabieniec bog and its palaeolake (central Poland) through the Late Weichselian and Holocene. Palaeogeogr Palaeoclimatol Palaeoecol 307:150-167. https://doi.org/10.1016/j.palaeo.2011.05.010

R Core Team (2015) R: A Language and Environment for Statistical Computing. Version 3.2.1. R Foundation for Statistical Computing, Vienna

Ralska-Jasiewiczowa M, Nalepka D, Goslar T (2003) Some problems of forest transformation at the transition to the oligocratic/Homo sapiens phase of the Holocene interglacial in northern lowlands of central Europe. Veget Hist Archaeobot 12:233-247. https://doi.org/10.1007/s00334-003-0021-8

Reille M (1999) Pollen et spores d'Europe et d'Afrique du Nord, 2nd edn. Laboratoire de Botanique Historique et Palynologie, Marseille

Reimer PJ, Bard E, Bayliss A et al (2013) IntCal13 and Marine13 radiocarbon age calibration curves $0-50,000$ years cal вР. Radiocarbon 55:1,869-1,887

Reingruber A, Thissen L (2009) Depending on 14C data: chronological frameworks in the neolithic and chalcolithic of southeastern Europe. Radiocarbon 51:751-770. https://doi.org/10.1017/ S0033822200056071

Rey F, Gobet E, Schwörer C et al (2019) Causes and mechanisms of synchronous succession trajectories in primeval Central European mixed Fagus sylvatica forests. J Ecol 107:1,392-1,408. https://doi.org/10.1111/1365-2745.13121

Roberts N, Fyfe RM, Woodbridge J et al (2018) Europe's lost forests: a pollen-based synthesis for the last 11,000 years. Sci Rep 8:716. https://doi.org/10.1038/s41598-017-18646-7
Rösch M (1992) Human impact as registered in the pollen record: some results from the western Lake Constance region, Southern Germany. Veget Hist Archaebot 1:101-109. https://doi.org/ 10.1007/BF00206090

Schoch WH, Pawlik B, Schweingruber F-H (1988) Botanische Makroreste: Ein Atlas zur Bestimmung häufig gefundener und ökologisch wichtiger Pflanzensamen. Haupt, Bern

Schwörer C, Henne PD, Tinner W (2014) A model-data comparison of Holocene timberline changes in the Swiss Alps reveals past and future drivers of mountain forest dynamics. Glob Chang Biol $20: 1,512-1,526$

Schwörer C, Colombaroli D, Kaltenrieder P, Rey F, Tinner W (2015) Early human impact (5000-3000 BC) affects mountain forest dynamics in the Alps. J Ecol 103:281-295. https://doi.org/10. 1111/1365-2745.12354

Skoglund P, Malmström H, Raghavan M et al (2012) Origins and genetic legacy of neolithic farmers and hunter-gatherers in Europe. Science 336:466-469. https://doi.org/10.1126/science. 1216304

Spiridonova E, Lavrushin YA (1997) Correlation of the geological and the paleoecological events of holocene of arctic, boreal and arid zones of East Europe. Quaternary geology and the paleogeography of Russia. Russian Academy of Sciences, Moscow, pp 151-170

Stockmarr J (1971) Tablets with spores used in absolute pollen analysis. Pollen Spores 13:615-621

Stolarek I, Handschuh L, Juras A et al (2019) Goth migration induced changes in the matrilineal genetic structure of the central-east European population. Sci Rep 9:6737. https://doi.org/10.1038/ s41598-019-43183-w

Tarasov P, Pushenko MY, Harrison S et al (1996) Lake status records from the former Soviet Union and Mongolia: documentation of the second version of the database. World Data Center-A for Paleoclimatology, Boulder

Telegin DY, Lillie M, Potekhina ID, Kovaliukh MM (2003) Settlement and economy in Neolithic Ukraine: a new chronology. Antiquity 77:456-470. https://doi.org/10.1017/S0003598X00092528

Ter Braak CJF, Prentice IC (1988) A theory of gradient analysis. In: Begon M, Fitter AH, Ford ED, Macfadyen A (eds) Advances in ecological research. Academic Press, London, pp 271-317

Ter Braak CJF, Šmilauer P (2017) Canoco. Version 5.1. Wageningen, Biometris

Thöle L, Schwörer C, Colombaroli D et al (2016) Reconstruction of Holocene vegetation dynamics at Lac de Bretaye, a high-mountain lake in the Swiss Alps. Holocene 26:380-396. https://doi. org/10.1177/0959683615609746

Tinner W, Hu F (2003) Size parameters, size-class distribution and area-number relationship of microscopic charcoal: relevance for fire reconstruction. Holocene 13:499-505

Tinner W, Lotter AF (2006) Holocene expansions of Fagus silvatica and Abies alba in Central Europe: where are we after eight decades of debate? Quat Sci Rev 25:526-549

Tinner W, Hubschmid P, Wehrli M, Ammann B, Conedera M (1999) Long-term forest fire ecology and dynamics in southern Switzerland. J Ecol 87:273-289. https://doi.org/10.1046/j.1365-2745. 1999.00346.x

Tinner W, Conedera M, Ammann B, Lotter AF (2005) Fire ecology north and south of the Alps since the last ice age. Holocene 15:1,214-1,226. https://doi.org/10.1191/0959683605hl892rp

Tinner W, Nielsen EH, Lotter AF (2007) Mesolithic agriculture in Switzerland? A critical review of the evidence. Quat Sci Rev 26:1,416-1,431. https://doi.org/10.1016/j.quascirev.2007.02.012

Tinner W, van Leeuwen JFN, Colombaroli D et al (2009) Holocene environmental and climatic changes at Gorgo Basso, a coastal lake in southern Sicily, Italy. Quat Sci Rev 28:1,498-1,510. https://doi.org/10.1016/j.quascirev.2009.02.001 
Tinner W, Vescovi E, van Leeuwen JFN et al (2016) Holocene vegetation and fire history of the mountains of Northern Sicily (Italy). Veget Hist Archaeobot 25:499-519. https://doi.org/10.1007/ s00334-016-0569-8

Tóth M, Magyari EK, Buczkó K et al (2015) Chironomid-inferred Holocene temperature changes in the South Carpathians (Romania). Holocene 25:569-582. https://doi.org/10.1177/0959683614 565953

Trautmann W (1953) Zur Unterscheidung fossiler Spaltöffnungen der mitteleuropäischen Coniferen. Flora 140:523-533

Van der Knaap WO (2009) Estimating pollen diversity from pollen accumulation rates: a method to assess taxonomic richness in the landscape. Holocene 19:159-163. https://doi.org/10.1177/ 0959683608098962

Van Raden UJ, Colombaroli D, Gilli A et al (2013) High-resolution late-glacial chronology for the Gerzensee lake record (Switzerland): $\delta^{18} \mathrm{O}$ correlation between a Gerzensee-stack and NGRIP. Palaeogeogr Palaeoclimatol Palaeoecol 391(Part B):13-24. https://doi.org/10.1016/j.palaeo.2012.05.017

Vinogradova O, Kiosak D (2017) Chronology of the north-west Pontic area: Common baseline for climatic and archaeological records (Mesolithic and Neolithic settlements). In: Makhortykh S, de Capitani A (eds) Archaeology and Palaeoecology of the Ukrainian steppe. National Academy of Sciences of Ukraine, Kiev

Von Grafenstein U, Belmecheri S, Eicher U et al (2013) The oxygen and carbon isotopic signatures of biogenic carbonates in Gerzensee, Switzerland, during the rapid warming around 14,685 years BP and the following interstadial. Palaeogeogr Palaeoclimatol Palaeoecol 391(Part B):25-32. https://doi.org/10.1016/j. palaeo.2013.08.018
Wagner S, Litt T, Sánchez-Goñi M-F, Petit RJ (2015) History of Larix decidua Mill. (European larch) since $130 \mathrm{ka}$. Quat Sci Rev 124:224-247. https://doi.org/10.1016/j.quascirev.2015.07.002

Walsh K, Berger J-F, Roberts CN et al (2019) Holocene demographic fluctuations, climate and erosion in the Mediterranean: a meta data-analysis. Holocene 29:864-885. https://doi.org/10.1177/ 0959683619826637

Whitlock C, Colombaroli D, Conedera M, Tinner W (2018) Land-use history as a guide for forest conservation and management. Conserv Biol 32:84-97. https://doi.org/10.1111/cobi.12960

Zakościelna A, Starkova E (2018) Traditions of ceramics production in the Central and Eastern Europe Eneolithic: tripolye, late Malice and Lublin-Volhynian cultures. Sprawozdania Archeologiczne 70:67-85

Zawiska I, Słowiński M, Correa-Metrio A et al (2015) The response of a shallow lake and its catchment to Late Glacial climate changes - a case study from eastern Poland. CATENA 126:1-10. https://doi.org/10.1016/j.catena.2014.10.007

Zernitskaya V (1991) Palaeogeography of the Byelorussian Polessie in the Late Glacial and Holocene. PhD thesis. Minsk University, Belarus

Zernitskaya V, Mikhailov N (2009) Evidence of early farming in the Holocene pollen spectra of Belarus. Quat Int 203:91-104. https:// doi.org/10.1016/j.quaint.2008.04.014

Publisher's Note Springer Nature remains neutral with regard to jurisdictional claims in published maps and institutional affiliations. 